Bull. Fac. Agric., Cairo Univ., 60:366 - 370 (2009)

\title{
ALKALOIDS OF Astragalus kahiricus DC. PLANT ROOTS
}

(Received: 1.7. 2009)

\author{
By \\ I. I. Mohamed, H.E. Hassan*, S. A. Ahmed** and S. M. Bahaa \\ Medicinal and Aromatic Plants Department, Desert Research Center, El-Matareya, Cairo, Egypt. \\ *Department of Botany, Faculty of Science, El-Monofiya University, Egypt. \\ ** Department of Applied Organic Chemistry, National Research Center, Giza, Egypt.
}

\begin{abstract}
While looking for the toxic principle of Astragalus kahiricus DC., a herb highly toxic in livestock especially in small ruminants, hypaphorine, the N,N,N-trimethyl tryptophan betaine was isolated. This alkaloid was identified in Astragalus kahiricus, using NMR and MS methods. It was synthesized in sufficient amount and tested for potential toxicity in mice and lambs. In this study it is shown, with good evidence, that hypaphorine could not be held responsible for Astragalus kahiricus poisonings in small ruminants.
\end{abstract}

Key words: Astragalus kahiricus, hypaphorine, small ruminants, toxicity.

\section{INTRODUCTION}

Astragalus kahiricus (Fabaceae) is found in some Mediterranean countries, where it was reported to be toxic for livestock, especially in Spain, Portugal and North Africa (Rodriguez et al.,1990). In Egypt, this plant is frequently responsible of intoxication in sheep and goats, especially in young animals (Abdennebi et al., 1998).

The poisonous species of Astragalus may be classified, on the basis of their toxic principles, into three main groups: (a) The group of the species termed locoweeds which is known to contain the alkaloid swainsonine (Stegelmeier et al., 1995). (b) The group of those containing the nitro compound: miserotoxin (Williams and Norris.1981). (c) The group of species that are selenium accumulators (Davis, 1972).

The toxic A. kahiricus in Egypt does not contain neither swainsonine nor miserotoxin, and contains only very low concentrations of selenium (Abdennebi and Lamnaouer, 1999). However, the clinical signs and lesions produced in intoxicated animals are dominated by epileptic crisis and cytoplasmic vacuolization in brain and other tissues (Moyano et al.,1989), and are similar to those caused by locoweeds (James et al., 1970).

Knowing that swainsonine is highly water soluble, it was found in the aqueous extract of the plant compound, which gives with Erlhich reagent a purple color on TLC like swainsonine. This compound was isolated and identified as hypaphorine. In the literature, this alkaloid was the subject of conflicting reports on its toxicity. On one hand it is considered as neurotoxic agent (Merck Index, 1976) and on the other hand it was reported to have only little pharmacological activity (Folkers and Koniuszy, 1939).

In order to verify if hypaphorine plays a role in the toxicity of Astragalus kahiricus, it was synthesized in sufficient amount and administered at relatively high doses to mice and lambs.

\section{MATERIALS AND METHODS \\ 2.1.Plant materials}

Astragalus kahiricus was collected in December 2007 in the region of El Sheikh Zuwyid, North Sinai, Egypt. In this area, frequent animal poisoning, by this plant species, are recorded each year in sheep herds.

\subsection{Isolation and purification of hypaphorine}

One $\mathrm{kg}$ of fresh plant root material was macerated in 2 liters of water, under continuous shaking, for $24 \mathrm{~h}$. The filtrate was evaporated under reduced pressure to yield $30 \mathrm{~g}$ of a dry extract. Six grams of the extract were dissolved in a small volume of water and chromatographed on reversed phase Silica gel RP2 (0.063-0.2 mm Merck), eluted 
with water and water methanol mixture. Thirty fractions were obtained, and controlled using TLC under UV light and after spraying with the Erlhich reagent. The fraction number 14 contains a major compound $\mathbf{X}$, which shows a purple color with Erlhich reagent. It was purified by preparative TLC using: Chloroform: methanol: ammonia (7/2.6/0.4) as a solvent system and identified as hypaphorine (21mg), which is colorless, mp $254-255^{\circ} \mathrm{C}$ (Ghosal and Srivastava, 1974).

\subsection{Synthesis of hypaphorine}

Hypaphorine was synthesized according to the method of (Von Romburgh and Barger, 1911). The L(-)-S-tryptophane $2.04 \mathrm{~g}$ (1 mmol) was dissolved in $25 \mathrm{ml}$ of methanol and added to a solution of 0.4 $\mathrm{g}$ of sodium hydroxide in $2 \mathrm{ml}$ of water. Then $8.52 \mathrm{~g}$ of methyl iodide $(6 \mathrm{mmol})$ were added to the mixture under magnetic stirring at $20-25{ }^{\circ} \mathrm{C}$. The solution was maintained alkaline, by addition of a small portion of sodium hydroxide $(0.85 \mathrm{~g})$ in $2 \mathrm{ml}$ of water, during $24 \mathrm{~h}$. After evaporation of methyl iodide (bp. $42.5^{\circ} \mathrm{C}$ ), the mixture was heated at $65^{\circ} \mathrm{C}$ for $1 \mathrm{~h}$ to hydrolyze the methyl ester to an acid. The solution was then acidified by addition of $\mathrm{HCl}$ $(10 \%)$. The hypaphorine chloride precipitate was washed with methanol, dissolved in methanolammonia and then chromatographed on Sephadex LH20 (30 g), eluted with methanol.The crystals formed in the first fractions are pure hypaphorine (1.8g): $\mathrm{mp} 252-255^{\circ} \mathrm{C},[\alpha] \mathrm{D}+140^{\circ} \mathrm{C}(\mathrm{C} 1, \mathrm{H} 2 \mathrm{O})$, MS (Electro-spray): $\mathrm{m} / \mathrm{z} 247[\mathrm{MH}]+,{ }^{1} \mathrm{H}$ and ${ }^{13} \mathrm{C}$ NMR (Table 1). These data agreed with those in the literature for this compound (Sarragiotto et al., 1981).

\subsection{Animals}

Three local breed lambs were used. They were purchased from the animal market and housed in a sheep box in the barn of the Faculty of Veterinary Medicine, Cairo University. They were fed good quality forage and water ad libitum. After one week of acclimatizing, they received one administration of hypaphorine solution in water $(100 \mathrm{mg} / \mathrm{ml})$ by oral route.

Sixteen week old balb-C mice were kindly provided by the Pharmacology Laboratory. They were housed 2 per cage in polyethylene cages and fed pellet food (Cicalim $\mathrm{n}^{\circ} 47$ ) and water ad libitum. After 1 week of acclimatation they were given hypaphorine solution. The solution of hypaphorine administered to mice by ip injection was prepared at concentration of $25 \mathrm{mg} / \mathrm{mL}$ in PBS solutions and sterilized by filtration through a membrane (porosity $0.22 \mu \mathrm{m}$ ) and administered by oral route. This was at a concentration of $100 \mathrm{mg} / \mathrm{ml}$ in tap water.

\subsection{Identification of the compound}

The ESI-TOFMS spectrum of the compound $\mathbf{X}$ showed the protonated molecular ion $[\mathrm{MH}]+$ at $\mathrm{m} / \mathrm{z}$ 247 suggesting formula $\mathrm{C}_{14} \mathrm{H}_{18} \mathrm{~N}_{2} \mathrm{O}_{2} \quad(\mathrm{M}=246)$ in agreement with ${ }^{13} \mathrm{C}$ NMR data (Table1). The Jmodulated ${ }^{13} \mathrm{C}$ spectrum presented $9 \mathrm{CH}$ or $\mathrm{CH}_{3}$ carbons, one $\mathrm{CH}_{2}$ and 4 quaternary carbons. Bidimensional NMR spectra ${ }^{1} \mathrm{H}-{ }^{13} \mathrm{C}$ HSQC and ${ }^{1} \mathrm{H}-$ ${ }^{1} \mathrm{H}$ COSY, assigned the 4 aromatic vicinal $\mathrm{CH}$ at ä $7.50,7.02,7.05$, and 7.35 of benzene ring, $3 \mathrm{H}$ in $\mathrm{CH}_{2}-\mathrm{CH}$ - system at ä 3.20 and 3.72 and $3 \mathrm{CH}_{3}$ in singulet at ä 3.07. The HMBC spectrum showed long-range correlations of 3 quaternary $\mathrm{sp} 2$ carbons at ä 108.96 with $\mathrm{H}-11 ; 128.27 \mathrm{H}-10$ and $\mathrm{H}-8$ and 138.04 with $\mathrm{H}-2, \mathrm{H}-5$ and $\mathrm{H}-7$, indicating the presence of the indolic skeleton and one remaining quaternary carbon at ä 171.62 assigned to carboxylic group.

Table (1): ${ }^{\mathbf{H}}$ and ${ }^{\mathbf{1 3}} \mathbf{C}$ NMR data of compound $\mathbf{x}\left(\mathbf{C D}_{\mathbf{3}} \mathbf{O D}\right)$.
\begin{tabular}{|c|c|lc|}
\hline $\mathbf{N}^{\mathbf{0}}$ & ${ }^{\mathbf{1 3}} \mathbf{C} \boldsymbol{\delta}(\mathbf{p p m})$ & \multicolumn{2}{|c|}{${ }^{\mathbf{1}} \mathbf{H} \boldsymbol{\delta}(\mathbf{p p m})$} \\
\hline 1 & - & $\mathrm{NH}$ & $10.17 \mathrm{~s}$ \\
\hline 2 & 125.11 & $\mathrm{CH}$ & $7.11 \mathrm{~s}$ \\
\hline 3 & 108.96 & $\mathrm{C}$ & - \\
\hline 4 & 128.27 & $\mathrm{C}$ & - \\
\hline 5 & 119.05 & $\mathrm{CH}$ & $7.50 \mathrm{~d}$ \\
\hline 6 & 120.04 & $\mathrm{CH}$ & $7.02 \mathrm{t}$ \\
\hline 7 & 122.60 & $\mathrm{CH}$ & $7.05 \mathrm{t}$ \\
\hline 8 & 112.45 & $\mathrm{CH}$ & $7.35 \mathrm{~d}$ \\
\hline 9 & 138.04 & $\mathrm{C}$ & - \\
\hline 10 & 24.65 & $\mathrm{CH}$ & $3.20 \mathrm{~d}$ \\
\hline 11 & 80.56 & $\mathrm{CH}$ & $3.72 \mathrm{t}$ \\
\hline 12 & 171.62 & $\mathrm{COO}-$ & - \\
\hline 13 & 52.66 & $\mathrm{~N}\left(\mathrm{CH}_{3}\right)_{3}$ & $3.07 \mathrm{~s}$ \\
\hline
\end{tabular}

The structure of compound $\mathbf{X}$ was thus identified to that of hypaphorine, N,N, N-trimethyl tryptophanium betaine (Figure 1).

\subsection{In vivo toxicity assay}

The ip administration of hypaphorine to mice at doses of 0.5 and $1 \mathrm{~g} / \mathrm{kg}$ body wt (Table 2), did not produce any sign of toxicity in animals. They tolerated even high doses of $2 \mathrm{~g} / \mathrm{kg}$ by oral route without any apparent toxic effect and survived until 
they were given an euthanasia solution 3 months later.

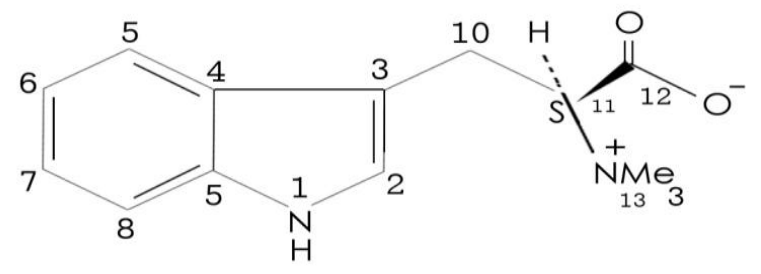

(X) Hypaphorine

Fig. (1): Structure of Hypaphorine.

Table (2): Toxicity assay in mice of hypaphorine solution by ip and oral routes.

\begin{tabular}{|c|c|c|c|}
\hline $\begin{array}{c}\text { Mouse } \\
\text { ID\# }\end{array}$ & $\begin{array}{c}\text { Body } \\
\text { weight (g) }\end{array}$ & $\begin{array}{c}\text { Dose } \\
(\mathbf{g} / \mathbf{K g})\end{array}$ & $\begin{array}{c}\text { Total amount } \\
\text { administered } \\
(\mathbf{m g})\end{array}$ \\
\hline 1 & 25 & $0.5^{a}$ & 12.5 \\
\hline 2 & 22.7 & $0.5^{a}$ & 11.4 \\
\hline 3 & 25.4 & $1^{a}$ & 25.4 \\
\hline 4 & 24.7 & $1^{a}$ & 25 \\
\hline 5 & 23.8 & $2^{b}$ & 47.6 \\
\hline 6 & 18.8 & $2^{b}$ & 40 \\
\hline
\end{tabular}

${ }^{a-}$. ip administration

${ }^{b-}$. po administration

The oral administration of hypaphorine to young lambs at doses of $0.5,1$, and $1.5 \mathrm{~g} / \mathrm{kg}$ body wt (Table 3) did not produce any abnormal sign in these animals.

Greshoff first discovered Hypaphorine in the

Table (3):Toxicity assay in lambs of hypaphorine solution by

\begin{tabular}{|c|c|c|c|}
\hline \multirow{2}{*}{$\begin{array}{c}\text { Lamb } \\
\text { ID \# }\end{array}$} & $\begin{array}{c}\text { Body } \\
\text { weight } \\
(\text { Kg) }\end{array}$ & $\begin{array}{c}\text { Dose } \\
(\mathrm{g} / \mathrm{Kg})\end{array}$ & $\begin{array}{c}\text { Hypaphorine } \\
\text { Total amount } \\
\text { administered } \\
(\mathbf{m g})\end{array}$ \\
\cline { 3 - 4 } & 7 & 0.5 & 3.5 \\
\hline 2 & 7 & 1 & 7 \\
\hline 3 & 6 & 1.5 & 9 \\
\hline
\end{tabular}

seeds of Erythrina hypaphorus Boel. Its chemical structure was described by (Von Romburgh and Barger, 1911) as an á-N,N,N-trimethyl+-âtryptophanium betaine (C14H18N2O2). Hypaphorine was later found in other plant species of the genus Erythrina (Folkers and Koniuszy, 1940). The literature on physiological activity of hypaphorine was carefully examined and it was found that even though the compound was reported to be a convulsive poison in the Merck Index. (1976) and other websites, there was no strong evidence to support this affirmation. In fact, hypaphorine, the betaine of tryptophan was first described to have no pronounced (but little) pharmacological activity (Folkers and Unna,1938).

Always in the ancient works, (Folkers and Unna.1938) reported the toxic curare-like action of the alkaloids in the seeds of Erythrina species, without mentioning precisely hypaphorine, one of the major alkaloid constituents of the seeds of these plants (2-3\%depending upon the species).

Some studies have shown the curare-like paralysis in frogs caused by natural alkaloids from Erythrina, such as erythramine (Folkers and Koniuszy, 1939). and others like erythraline, âerythroidine (LD50 $24 \mathrm{mg} / \mathrm{kg}$, ip, in mice) (Folkers and Koniuszy, 1940). Also, some alkaloids isolated after hydrolysis of an aqueous extract known to have curare-like action in frogs, such as erysodine, erysopine, erysicine and erisivine.This fact suggested the presence of glycosides of alkaloids, which are very water soluble (Folkers and Koniuszy, 1939). Later, they was isolated: on one hand the glycosides: 15-O-â-D-glucoerysovine (Amer et al., 1991), and 16-O-â.D-glucoerysovine (Wandji et al., 1995) and, on the other hand the esters of hypaphorine: (Fig. 2) erysophorine $(=15$ hypaphorinoxyerysovine) (Ghosal and Srivastava 1974) and erysodinophorine $\quad(=16-$ hypaphorinoxyerysovine) (Tiwari and Masood. 1979). 

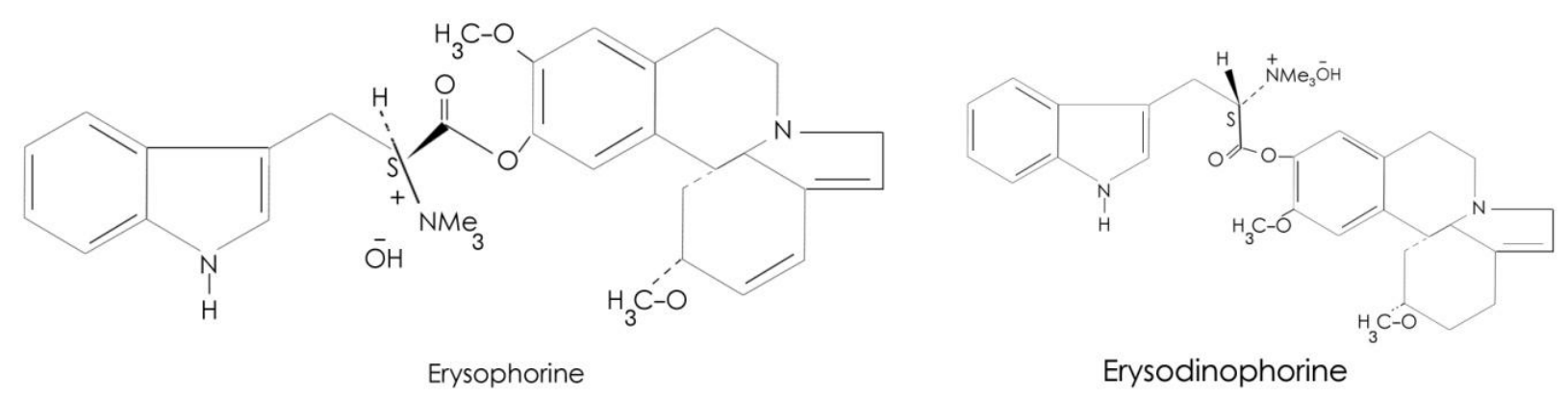

Fig. (2): Some toxic alkaloids

It should be noted that a derivative of hypaphorine, the methyl á-dimethylamino-â-(3indole)-propionate methiodide has an LD50 of 450 $\mathrm{mg} / \mathrm{kg}$ in mice (Folkers and Unna, 1938).

On the basis of this historical data, it was decided to test hypaphorine in mice by injection of high doses of $500 \mathrm{mg} / \mathrm{kg}$ up to $2000 \mathrm{mg} / \mathrm{kg}$. No toxic effects were observed.

Being aware of any species response variation, hypaphorine was also tested in lambs. Despite the oral administration of relatively high doses of pure alkaloid $(0.5 ; 1$ and $1.5 \mathrm{~g} / \mathrm{kg})$ compared to lethal dose of the whole plant (5 $\mathrm{g} / \mathrm{kg}$ dry weight) (Abdennebi et al.,1998), these doses didn't produce any toxic effect. Thus, by testing hypaphorine in lambs, the most sensitive animals to A. lusitanicus poisoning, in the field and experimental conditions, this study presents good evidence that hypaphorine could not be responsible for the toxicity of this plant species. Moreover, it can be suggested that the affirmation saying that hypaphorine is a convulsive agent, as it is stated in the Merck Index (1976), should be reconsidered. It may also be concluded that the confusion about the toxicity of hypaphorine came from the fact that hypaphorine part in erysophorine and erysodinophorine molecules (Figure 2), makes these alkaloids more water soluble and thus enhances their curare-like activity in the frogs.

However, free hypaphorine produced no toxicity, whereas the other parts of erysophorine and erysodinophorine were toxic. Thus, the results showing that hypaphorine has no toxic effect in mice and lambs are in agreement with the literature data.

\section{REFERENCES}

Abdennebi E.H. and Lamnaouer D.(1999). Investigations on the toxic principle of Astragalus lusitanicus Lam. Actes Inst. Agron. Vet. (Maroc). 19: 205-210.

Abdennebi E.H., El Ouazzani N. and Lamnaouer D. (1998). Clinical and analytical studies of sheep dosed with various preparations of Astragalus lusitanicus. Vet. Hum. Toxicol. 40: 327-331.

Amer M.E., El-Masry S., Shamma M. and Freyer A.J. (1991). Three novel glycodienoid alkaloids from Erythrina lysistemon. J. Nat. Prod. 54: 161-166.

Davis A.M. (1972). Selenium accumulation in Astragalus species. Agronomy J.64: 751-754.

Folkers K. and Koniuszy F. (1939). Erythrina alkaloids. III. Isolation and characterization of a new alkaloid, erythramine.J.Am.Chem. Soc. 61:1332-1335.

Folkers K. and Koniuszy F. (1940). Erythrina alkaloids. IV. Isolation and characterization of Erysodine, Erysopine, Erysocine and Erysovine. J. Am. Chem. Soc. 62: 1677-1683.

Folkers K. and Unna K.,(1938). Erythrina alkaloids. II. A review, and new data on the alkaloids of species of the genus Erythrina. J. Am. Pharmacoeut. Assoc. 27: 689-693.

Ghosal S. and Srivastava R.S. (1974). Structure of Erysophorine: A new quaternary alkaloid of Erythrina arborescens. Phytochemistry. 13: 2603-2605.

James L.F., Van Kampen K.R. and Hartley W. J. (1970). Comparative pathology of Astragalus 
(Locoweed) and Swainsona poisoning in sheep. Path. Vet. 7:116-125.

Merck Index (1976). $7^{\text {th }}$ ed.MarthaWind ho/Z ed., Merck \& Co. Rahway, N.I. USA, p:647.

Moyano Salvago R., Gazquez Ortiz A., Garcia Roman A. and Infanfe Miranda F. (1989). Alteraciones anatomopatologicas producidas en la intoxication experimental por Astragalus lusitanicus Lam. Med. Vet. 6:491494.

Rodriguez F.S., Roman A.G., and Salvego M.R. (1990). Effect of Astragalus lusitanicus Lam. in experimental subchronic neurotoxicity of lambs. Vet. Hum. Toxiciol. 32: 551- 554.

Sarragiotto M.H., Folio H. L. and Marsaiolo A.J. (1981). Erysotrine-N-oxide and erythrartineNoxide, two novel alkaloids from Erythrina mulungu. Can. J. Chem 59: 2772-2773.

Stegelmeier B.L., James L.F. and Panter K.E. (1995). Tissue and serum swainsonine concentration in sheep ingesting Astragalus lentiginosus (Locoweed). Vet. Hum. Toxicol. 37: 336-339.

Tiwari K.P., and Masood M., (1979). Alkaloids from pods of Erythrina arborescens. Phytochemistry. 18: 704-705.

Von Romburgh P. and Barger G. (1911). Preparation of betaine of tryptophan and its identity with the alkaloid hypaphorine. J.Am. Chem. Soc. 99:2068-2071.

Wandji J., Awanchiri S.S., Fomum Z.T., Tillequin F., and Libot F. (1995) Isoflavones and alkaloids from the stem bark and seeds of Erythrina senegalensis. Phytochemistry. 39: 677-681.

Williams M.C. and Norris F. A. (1981). Nitro compounds in foreign species of Astragalus. Weed Sci. 29: 261-269.

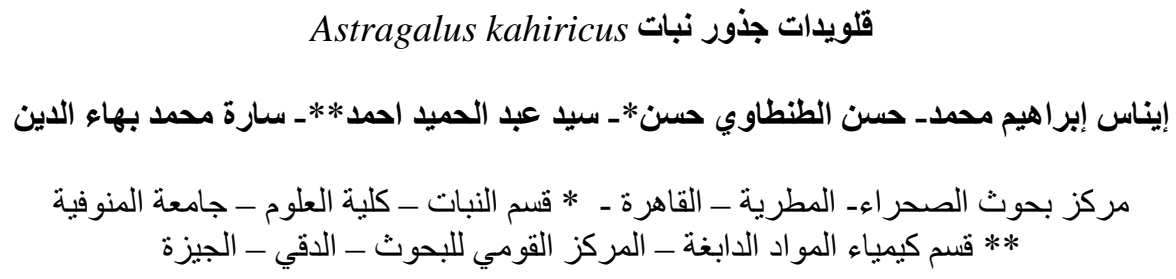

ملخص الترو

يتبر Astragalus kahiricus نبات عالي السمية في الثروة الحيو انية وخاصة في الحيوانات المجترة الصغيرة. تم عزل ملئ مادة الهيبافورين وهى عبارة عن N-N-trimethyl tryptophan betaine وتم التعرف على التى هذا المركب القلويدي بطرق التحليل الطيفي

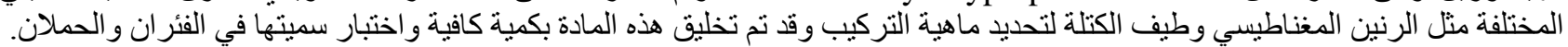
أظهرت هذه الدراسة أن مادة الهيبافورين في نبات stragalus kahiricus لايمكن أن نكون مسئولة عن حالات التسمم في الحيو انات

المجترة الصغيرة.

المجلة العلمية لكلية الزراعة - جامعة القاهرة - المجلا (60) العدد الرابع (أكتوبر 2009 ):370-366. 